\title{
Spread of the invasive shell-boring annelid Polydora websteri (Polychaeta, Spionidae) into naturalised oyster reefs in the European Wadden Sea
}

\author{
Andreas M. Waser ${ }^{1}$ (D) Dagmar Lackschewitz ${ }^{1} \cdot$ Jeffrey Knol $^{2} \cdot$ Karsten Reise $^{1} \cdot \mathrm{K}^{\text {. Mathias Wegner }}{ }^{1}$ (D) \\ David W. Thieltges ${ }^{2}$
}

Received: 14 May 2020 / Revised: 1 July 2020 / Accepted: 6 July 2020 / Published online: 5 August 2020

(C) The Author(s) 2020

\begin{abstract}
With globally growing aquaculture activities, the co-introduction of parasites alongside large-scale movements of commercial species poses an increasing risk for marine ecosystems. Here, we present the first record of the shell-boring polychaete Polydora websteri Hartman in Loosanoff and Engle, 1943 in invasive Pacific oysters Crassostrea (Magallana) gigas (Thunberg, 1793) in the European Atlantic Ocean. In October 2014, mud blisters in the shells of wild Pacific oysters and specimens of a spionid polychaete were observed in close proximity to a commercial oyster farm at the island of Sylt (Germany) in the European Wadden Sea. Subsequent investigations indicated that these blisters only occurred near the farm and that no other mollusc species were affected. Morphological and molecular analysis identified the polychaete as Polydora websteri, a species that nowadays widely occurs around the globe, but likely is native to the Asian Pacific. Later sampling activities detected $P$. websteri also at other locations around Sylt as well as in the Dutch part of the Wadden Sea at the island of Texel. The number of polychaetes in the oysters was, however, relatively low and mostly below 10 individuals per oyster. Together, this evidence suggests that $P$. websteri is currently extending its range. As the introduction of $P$. websteri may have severe ecological and economic implications, this study aims to alert others to look for $P$. websteri at Western European coasts within farmed or wild Pacific oysters to further document its spread.
\end{abstract}

Keywords Aquaculture $\cdot$ Co-introduction $\cdot$ Crassostrea gigas $\cdot$ Mud blister $\cdot$ Parasitism

\section{Introduction}

Global trade has increased enormously during the last decades resulting in an unparalleled introduction of species across the planet (Vitousek et al. 1996; Mack et al. 2000). Besides transport in vessel ballast water or as hull fouling on ships, direct and indirect introductions via aquaculture activities are the

Communicated by P. Lana

Andreas M. Waser

andreas.waser@awi.de

1 Alfred Wegener Institute, Helmholtz Centre for Polar and Marine Research, Wadden Sea Station Sylt, Hafenstraße 43, 25992 List, Sylt, Germany

2 Department of Coastal Systems, NIOZ Royal Netherlands Institute for Sea Research and Utrecht University, PO Box 59, 1790 Den Burg, AB, Netherlands most important invasion vectors for marine ecosystems (Katsanevakis et al. 2013). The latter occur mainly via the deliberate import of commercial species and the subsequent transfer of farmed specimens between aquaculture sites. For example, the culture of marine molluscs has frequently been described as a gateway for species introductions as it is often accompanied by large-scale stock movements (Wolff and Reise 2002; Ruesink et al. 2005; McKindsey et al. 2007). Some species, such as the Pacific oyster Crassostrea (Magallana) gigas (Thunberg, 1793), have been repeatedly translocated into new environments and are nowadays traded and cultured globally (Ruesink et al. 2005; Lucas 2019). Consequently, associated organisms that live in or on the oysters, such as sessile and boring species or parasites, have also unintentionally been introduced outside their native range (Elton, 1958; Goedknegt et al. 2016; Feis et al. 2019). One group of organisms that is likely to be co-introduced with commercial molluscs are shell-boring polychaetes, of which polydorins are the most common group (Blake 1969; 
Boonzaaier et al. 2014). These worms are known to penetrate mollusc shells and form burrows therein (Simon and SatoOkoshi 2015). In cases of heavy infestations, shells are severely damaged by the boring activity of the worms which may negatively affect host condition as the hosts divert energy from growth to shell repair (Kent 1979; Lleonart et al. 2003). In addition, shell damage reduces shell strength which in turn can lead to increased predation by crabs and other predators (Ambariyanto and Seed 1991; Buschbaum et al. 2007).

A polydorin species often co-introduced with cultured molluscs is Polydora websteri Hartman in Loosanoff and Engle, 1943 (Simon and Sato-Okoshi 2015; Rice et al. 2018). This species causes mud-filled blisters inside mollusc shells. These so-called mud blisters are the result of the polychaete's feeding activity that leads to the accumulation of detritus, mud, and faecal particles inside the burrow and the production of additional shell layers by the host to cover the burrow of the intruding worm. The polychaete is considered a serious pest in commercial marine aquaculture throughout the globe, as mud blisters decrease the market value of the infested molluscs (Whitelegge 1890; Lunz 1941; Loosanoff and Engle 1943; Bailey-Brock and Ringwood 1982; Ogburn et al. 2007).

Polydora websteri is deemed to be native to Asian coasts (Rice et al. 2018) but has also been reported from several locations all over the world including Australia, New Zealand, Hawaii, Brazil, the Atlantic and Pacific coasts of North America, and the Black Sea in Europe (Read 2010; Surugiu 2012; Sato-Okoshi and Abe 2013; Barros et al. 2017; Ye et al. 2017; Rice et al. 2018; Martinelli et al. 2020). Since it is often associated with economically important mollusc species that are cultured globally, such as C. gigas, it is possible that the polychaete will extend its range along coastal areas in the future.

In Europe, Pacific oysters have been cultured for several decades as alternative to the native European flat oyster Ostrea edulis Linnaeus, 1758, which was driven to extinction due to overexploitation in many European coastal areas by the 1950s (Troost 2010). The first $C$. gigas were deliberately introduced to several locations along the European Atlantic coast for cultivation purposes in the 1960s and 1970s in the belief that water temperatures were too cold to allow for natural reproduction of the oysters (Troost 2010). This assumption proved to be wrong and wild Pacific oyster populations established along much of the European shoreline (see reviews of Troost 2010, Herbert et al. 2016). This was also true for the Wadden Sea, where oysters mostly settled on epibenthic beds of blue mussels Mytilus edulis Linnaeus, 1758, and led to the creation of persisting mixed populations of mussels and oysters (Waser et al. 2016, Reise et al. 2017b, van der Meer et al. 2019). The oyster populations of the Wadden Sea originate from two different sources (Moehler et al. 2011). One population stems from oyster farms in the Dutch Delta, from which individuals were deliberately brought to Texel in the Dutch Wadden Sea in the late 1970s and later spread throughout large parts of the Wadden Sea (Troost 2010). The other population in the northern Wadden Sea descends from an oyster farm at Sylt in the German Wadden Sea (Reise 1998, Moehler et al. 2011), which started importing C. gigas from the British Isles in 1986.

In the Wadden Sea, molluscs like common periwinkles Littorina littorea (Linnaeus, 1758), blue mussels, and Pacific oysters are heavily infested by the small native shell-boring polychaete Polydora ciliata (Johnston, 1838). This is easily recognizable by tiny U-shaped burrows lacking dark inclusions. In contrast, in October 2014, Pacific oysters with dark blisters inside the shell (see Fig. 1a) were observed at Blidselbucht (Site 2, see Fig. 2) at northern Sylt adjacent to the only commercial oyster farm of that region. The blisters harboured polydorin worms (Fig. 1b-d) that were of unknown identity and apparently new to the Wadden Sea area. Subsequently, mollusc shells, in particular of Pacific oysters, were investigated for signs of this polychaete throughout the Wadden Sea. Our results represent the first records of $P$. websteri in the Wadden Sea and along the European Atlantic coastline.

\section{Material and methods}

After the first sighting of the newly introduced polydorin species, several locations along the eastern coastline of the German Wadden Sea island Sylt and one location at the coast of the Dutch Wadden Sea island Texel were investigated for blisters in live Pacific oysters and in empty oyster shells during autumn 2014. Similarly, other potential hosts, such as mussels and periwinkles, were examined for infestations of this polychaete at Blidselbucht. In some cases, blisters of live oysters and empty shells were opened to check whether they harboured polydorin worms. The polydorins were morphologically inspected and compared with descriptions of species known to occur in the European Atlantic Ocean (Radashevsky 2012). Since our specimens did not match any of these descriptions, they were also compared with descriptions of polydorins from the Asian Pacific Ocean (Sato-Okoshi 1999), where Pacific oysters originate from.

In subsequent years, oysters were not systematically screened, but gaping shells of recently died oysters were inspected for blisters during other sampling activities throughout the entire Wadden Sea (see Fig. 2), and locations with putative positive records were noted. Blisters provide useful information concerning the geographical spread of the polychaete, albeit only of advanced stages of infestation. Thus, recently infested oysters harbouring worm burrows still lacking mud blisters were missed out. 
Fig. 1 Crassostrea gigas infested with Polydora websteri collected from Blidselbucht at Sylt in the German Wadden Sea. a Inner surface of infested valves of $C$. gigas showing mud blisters caused by $P$. websteri; $\mathbf{b}$ close up of an opened mud blister inhabited by $P$. websteri; c overview of a single specimen of $P$. websteri; and $\mathbf{d}$ black lines on the sides of the palps of P. websteri. Photo copyrights: Dagmar Lackschewitz
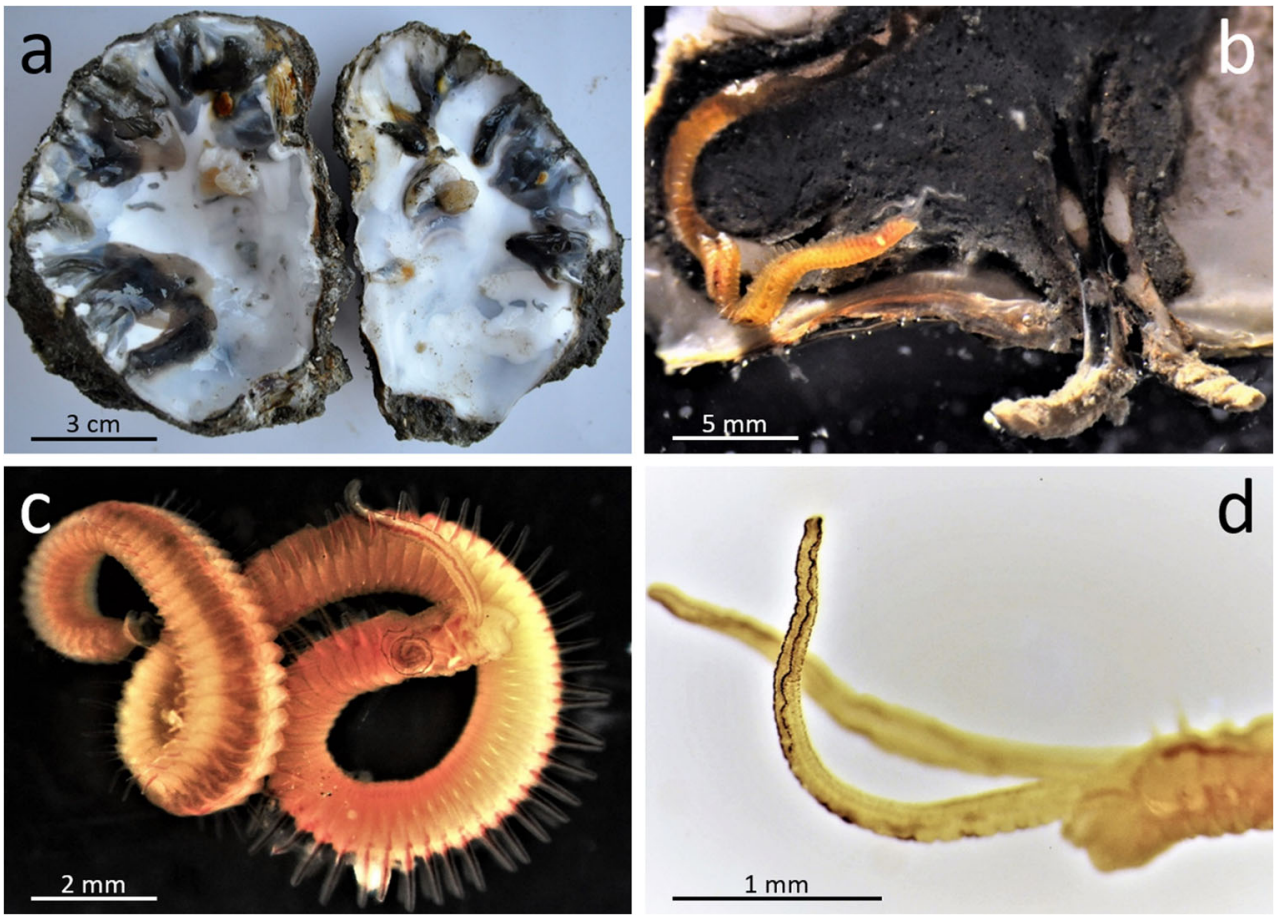

Fig. 2 Sampling locations where Pacific oysters, mussels, and periwinkles were studied for presence of Polydora websteri in the Wadden Sea from 2014 onwards. Locations where individuals or blisters of $P$. websteri were recorded are represented by squares, while circles indicate negative records. The inserts show the two sampling areas in the northern (Sylt) and southern (Texel) Wadden Sea, where an initial survey in 2014 took place and where $P$. websteri was recorded. For sampling dates (year, month) and numbers of investigated Pacific oysters, oyster shells, mussels, or periwinkles, see Table 1. The year dates next to the smaller circles in the overview map indicate the last visit to a respective location with a negative record. The dashed lines represent country borders

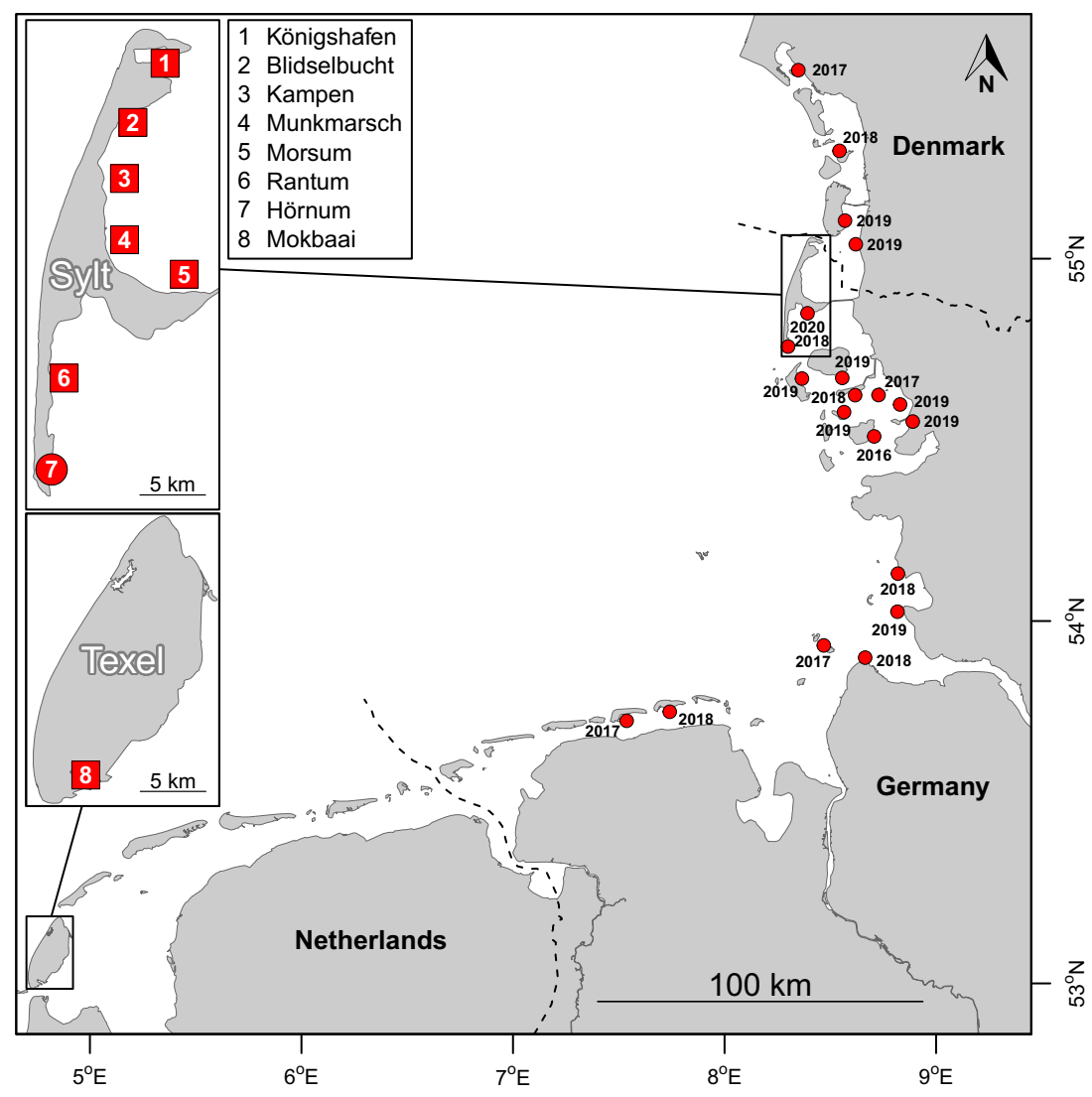


Fig. 3 Phylogenetic tree based on mitochondrial COI sequences.

Tree topology is based on

Kimura-2-parameter distance matrix and rooted with a sequence of Pseudopolydora dayii as outgroup. Bootstrap support out of 1000 replicates is shown for branches with $>95 \%$ support. Accession numbers are given for each sequence. Origin of the sequences is given for the $P$. websteri clade, and sequences generated in this study are shown in bold

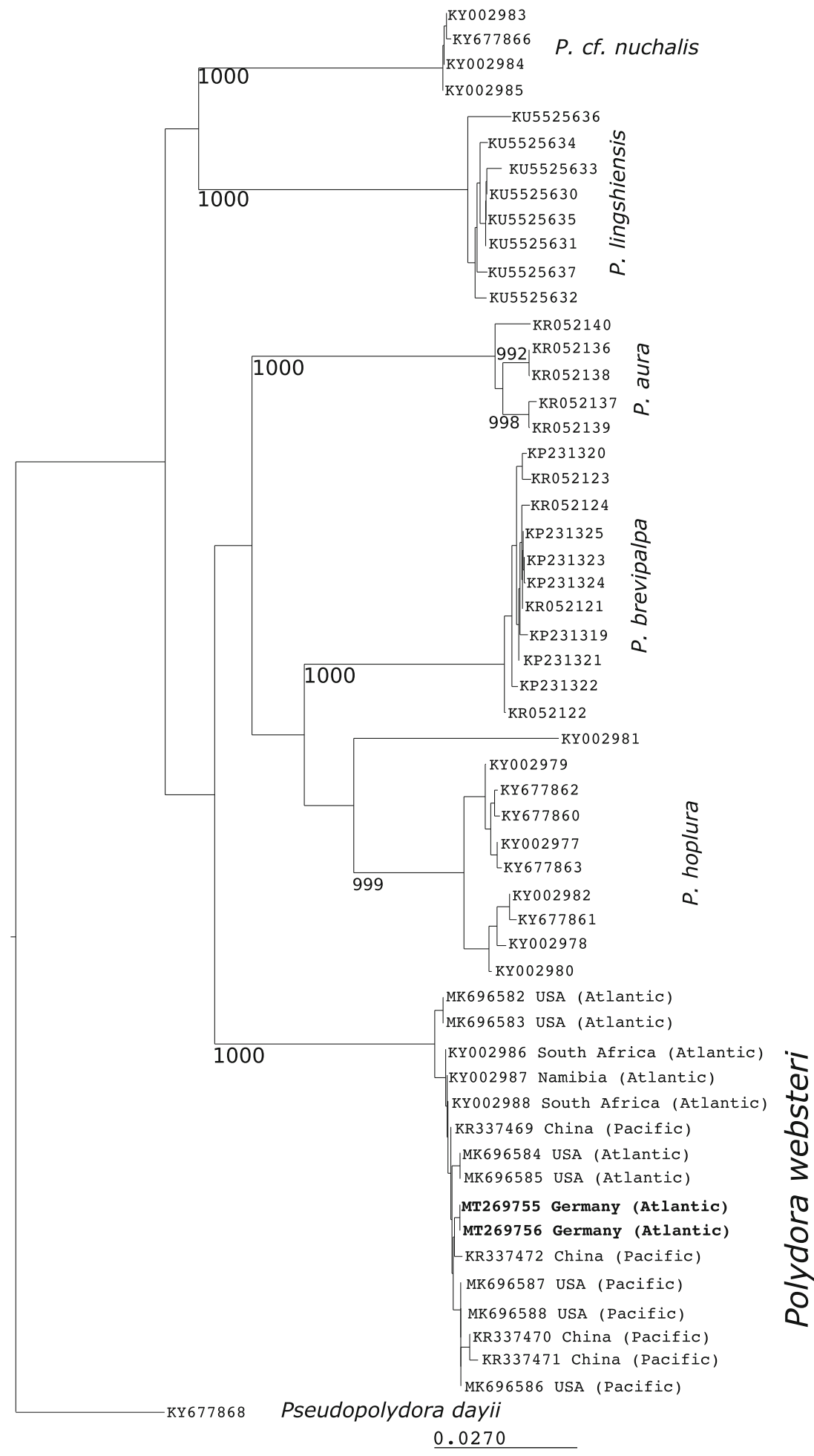

In March 2017, nine Pacific oysters gathered from Blidselbucht were examined to assess the number of blisters per individual oyster, and in late summer/early autumn 2017 , a systematic survey was conducted at the two Wadden Sea islands Sylt and Texel. On Sylt, mussels and oysters were sampled at Blidselbucht in August 2017 and on Texel at Mokbaai in October 2017 (Fig. 2). Overall, 41 Pacific oysters $($ Sylt $=19$, Texel $=22)$ and 229 blue mussels $($ Sylt $=79$, Texel $=150$ ) were randomly collected from the intertidal zone. All collected individuals were incubated overnight in a 
solution of one-part ethanol $96 \%$ and twenty parts seawater (similar to the 1:20 solution of phenol and seawater used by Handley (1995)) to drive the boring polychaetes out of the shells. The efficiency of the solution had been tested on five oysters, whose shells were completely broken after treatment and carefully investigated for $P$. websteri presence. In all broken oyster shells, no individuals of $P$. websteri were found in addition to the ones that had left the shells overnight. All polydorins were identified and counted per individual mussel or oyster. Prevalence was calculated as the proportion of infested oysters and mussels in each sample. In summer 2018, another sample of 30 Pacific oysters taken at Blidselbucht was inspected for blisters.

\section{Molecular identification}

Morphological characteristics of some polydorin species display high variability, which may compromise the species identification based on morphological characteristics (e.g. Sato-Okoshi and Abe 2013). In order to confirm the species identity, two individuals collected from Blidselbucht in early 2019 that showed the same morphological characteristics as previously collected specimens were used for molecular species identification based on cytochrome c oxidase I (mtCOI) as a molecular marker. DNA of both specimens was extracted using the DNeasy Plant Mini Kit (Qiagen, Hilden, Germany) following the manufacturer's instructions. A $\sim 680 \mathrm{bp}$ fragment of COI was amplified using the annelid primers X1-F2 C C W G A T A T R G C A T T C C C a n d X 1 - R 2 GCKARYCADCTAAATACTTTAA (Ye et al. 2017) in a PCR reaction containing $10 \mu \mathrm{l}$ of $2 \mathrm{x}$ Hot Star Polymerase Mastermix (Qiagen, Hilden, Germany), $1.5 \mu \mathrm{l}$ of each primer $(5 \mu \mathrm{M})$, and $2 \mu \mathrm{l}$ of DNA extract in $20 \mu \mathrm{l}$ reaction volume. Cycling consisted of $5^{\prime}$ hot start activation at $95^{\circ} \mathrm{C}$, followed by 35 cycles of $50^{\prime \prime}$ at $94^{\circ} \mathrm{C}, 50^{\prime \prime}$ at $50^{\circ} \mathrm{C}$ annealing and $1^{\prime} 30^{\prime \prime}$ extension at $72{ }^{\circ} \mathrm{C}$ before ending the reaction with a final extension of $10^{\prime}$ at $72^{\circ} \mathrm{C}$. The PCR products were purified using the Qiaquick DNA purification kit (Qiagen, Hilden, Germany), and $75 \mathrm{ng}$ of the purified products were sequenced from both ends by Eurofins Genomics (Ebersberg, Germany). Forward and reverse reads were assembled using CLC Genomics Workbench v. 8.5 (Qiagen, Hilden, Germany), manually curated and trimmed of primer sequences. The obtained sequences were aligned together with other Polydora sequences retrieved from GenBank using muscle (Edgar, 2004). A phylogenetic neighbour joining tree was constructed based on a Kimura-2-parameter distance matrix rooted with the COI sequence of Pseudopolydora dayii (GenBank accession: KY677868), and the resulting tree topology was tested against 1000 bootstrap replicates using the software Seqotron v1.0.1 (Fourment and Holmes 2016).

\section{Results}

\section{Morphological characteristics}

The spionid worms found in blisters of Pacific oysters were generally about $40-50 \mathrm{~mm}$ long when alive or anaesthetised in a $\mathrm{MgCl}_{2}$-solution, with the largest specimen anaesthetised measuring $60 \mathrm{~mm}$. Specimens preserved in ethanol shrank to $<20 \mathrm{~mm}$. The most striking characteristics in live animals were thin black lines along the feeding grooves of the palps (see Fig. 1d). In the majority of specimens examined, they appeared as continuous dark lines but could also consist of non-continuous bands or were missing in a few cases. These lines started to fade out when the animals were preserved in ethanol or formalin. Apart from that, there was no dark body pigmentation. The prostomium was bilobed and more or less incised. Two pairs of eyes were in trapezoidal arrangement, while an occipital antenna was absent. The caruncle seemingly extended up to the third segment. Chaetiger 1 only showed neuropodial setae with the notopodial setae missing. Chaetiger 5 was elongated compared with adjacent segments. Its major modified spines were falcate with a lateral flange on the concave side, and the companion chaetae were hastate and showed partly frayed tips. From chaetiger 7 onwards, hooded hooks with constrictions on the shafts were present. Also from chaetiger 7, branchiae continued almost to the rear end. The pygidium was generally disc-like with a distinct dorsal gap but in some specimens tended to be more cup-shaped.

All these characteristics combined did not match up with polydorin species known from the European Atlantic (Radashevsky 2012), suggesting that the species was new to the area. Instead, the morphological features generally corresponded to descriptions of Polydora websteri (Radashevsky 1999; Sato-Okoshi 1999; Read 2010; Sarugiu 2012; Barrows et al. 2017; Ye et al. 2017).

\section{Molecular identification}

The COI sequences of the investigated specimens were 679 bp in length (GenBank accessions: MT269755, MT269756). Both sequences clustered with the other sequences assigned to Polydora websteri and were separated with high bootstrap support from the other Polydora species (i.e. P. hoplura, P. brevipalpa, P. aura, $P$. lingshiensis, and P. nuchalis, Fig. 3). Therefore our molecular identification matches the morphological identification indicating that also the other specimen that were not subjected to molecular identification were correctly assigned to $P$. websteri. Within the $P$. websteri clade, the sequences generated from the specimens used here were located in a cluster of similar sequences that were isolated from worms collected in the Pacific (China, USA) as well as in the Atlantic Ocean (Namibia, South Africa, 
USA). The global distribution of sequence origins within this cluster further supports the recent global spread of this species (Martinelli et al. 2020).

\section{Infestation prevalence and dose}

In total, 271 Pacific oysters and 130 single shells of dead oysters were observed systematically for $P$. websteri infestation. In 2014, the period where the polychaete was first recorded in the Wadden Sea, blisters of $P$. websteri could only be detected in oysters from Blidselbucht, while oysters at other investigated locations showed no signs of $P$. websteri infestation (Table 1). There were also no indications that $P$. websteri infected other species, like mussels and periwinkles (Table 1). The prevalences at Blidselbucht in autumn 2014 were $80-90 \%$ in alive Pacific oysters and $60-70 \%$ in gaping valves of recently died oysters.

As of 2016, Pacific oysters showing mud blisters were also found at the northern end of Sylt at Königshafen (location 1), Kampen (location 3), and Munkmarsch (location 4, Table 1,
Fig. 2). In 2020, blisters were furthermore observed close to the causeway connecting Sylt with the mainland at Morsum (location 5) and at the southern end of Sylt near Rantum (location 6, Table 1, Fig. 2). In autumn 2017, blisters in Pacific oysters and specimens of $P$. websteri were found at the island of Texel in the Dutch Wadden Sea. At the other locations throughout the Wadden Sea (Fig. 2), no blisters were found in all shells of dead and gaping Pacific oysters. All six of the new records showed rather low occurrences of $P$. websteri (prevalence on Texel $14 \%$ and very few oysters featuring blisters at the other locations at Sylt (Table 1, Reise pers. obs.), compared with the area around the oyster farm at Blidselbucht, where the prevalence was found to be relatively high with $42 \%$ and $77 \%$ in 2017 and 2018, respectively (Table 1). With respect to the infection dose of individual oysters sampled in autumn 2017, the average intensity of $P$. websteri in the oysters was $3.18 \pm 3.43 \mathrm{SD}$, with the highest record of 11 individuals of $P$. websteri in an oyster from Blidselbucht (Table 2). Considering the number of blisters per oyster, a maximum of 12 blisters was observed in a 15.5-cm-long oyster (Table 2).

Table 1 Locations as well as year and month (beginning with first record) at which Pacific oysters, mussels, and periwinkles were investigated in the Wadden Sea from 2014 onwards

\begin{tabular}{|c|c|c|c|c|c|c|c|c|}
\hline Location & Code & Year & Month & Species & $n$ & Oysters with $P$. websteri & Prevalence & Pathology \\
\hline Blidselbucht, Sylt & 2 & 2014 & 10 & Oysters & 10 & 8 & $80 \%$ & Blisters, live worms \\
\hline Blidselbucht, Sylt & 2 & 2014 & 10 & Single shells of dead oysters & 20 & 12 & $60 \%$ & Blisters \\
\hline Königshafen, Sylt & 1 & 2014 & 11 & Oysters & 40 & 0 & 0 & \\
\hline Blidselbucht, Sylt & 2 & 2014 & 11 & Oysters & 55 & 48 & $87 \%$ & Blisters, live worms \\
\hline Blidselbucht, Sylt & 2 & 2014 & 11 & Single shells of dead oysters & 110 & 80 & $73 \%$ & Blisters \\
\hline Blidselbucht, Sylt & 2 & 2014 & 11 & Mussels & 45 & 0 & 0 & \\
\hline Blidselbucht, Sylt & 2 & 2014 & 11 & Periwinkles & 12 & 0 & 0 & \\
\hline Kampen, Sylt & 3 & 2014 & 11 & Oysters & 40 & 0 & 0 & \\
\hline Hörnum, Sylt & 7 & 2014 & 11 & Oysters & 13 & 0 & 0 & \\
\hline Mokbaai, Texel & 8 & 2014 & 11 & Oysters & 30 & 0 & 0 & \\
\hline Königshafen, Sylt & 1 & 2015 & 4 & Oysters & NA & 1 & NA & Blisters \\
\hline Kampen, Sylt & 3 & 2016 & 1 & Oysters & NA & 1 & NA & Blisters \\
\hline Munkmarsch, Sylt & 4 & 2016 & 7 & Oysters & NA & 3 & NA & Blisters \\
\hline Blidselbucht, Sylt & 2 & 2017 & 8 & Oysters & 19 & 8 & $42 \%$ & Blisters, live worms \\
\hline Blidselbucht, Sylt & 2 & 2017 & 8 & Mussels & 79 & 0 & 0 & \\
\hline Mokbaai, Texel & 8 & 2017 & 10 & Oysters & 22 & 3 & $14 \%$ & Blisters, live worms \\
\hline Mokbaai, Texel & 8 & 2017 & 10 & Mussels & 150 & 0 & 0 & \\
\hline Blidselbucht, Sylt & 2 & 2018 & 7 & Oysters & 30 & 23 & $77 \%$ & Blisters \\
\hline Rantum, Sylt & 6 & 2020 & 4 & Oysters & NA & 4 & NA & Blisters \\
\hline Morsum, Sylt & 5 & 2020 & 5 & Oysters & 12 & 4 & $25 \%$ & Blisters \\
\hline
\end{tabular}

For each location, the number of collected mollusc species (mussels, periwinkles, and oysters (alive and dead shells)) is given as well as the number of specimens where Polydora websteri was found either based on shell blisters or on the identification of polydorin species (only 2017). Moreover, the prevalence per species and location is given. Note that for locations where only qualitative data exist, only the date of the first record is given. NAs indicate cases that were inspected qualitatively, and hence, no information on the sample size and prevalence exist 


\section{Discussion}

Our findings constitute the first evidence that the shell-boring polychaete Polydora websteri is present in the Wadden Sea and document its expansion to the European Atlantic coast. Previous reports indicated that this species has spread widely around the globe, supposedly distributed by means of shellfish translocations (Simon and Sato-Okoshi 2015; Rice et al. 2018). According to this, previous records of $P$. websteri often stem from farmed oysters (see Simon and Sato-Okoshi 2015). Interestingly, we first detected the polychaete at a site (location 2: Blidselbucht) in close proximity to a commercial oyster farm where juvenile Pacific oysters are imported primarily from a nursery in southern Ireland, supplied by British hatcheries. These oysters of about $50 \mathrm{~mm}$ in length are kept on trestles and usually reach marketable size within 2 years, spending winter months indoors to avoid damage by ice. We found $P$. websteri in the direct vicinity of the trestles in discarded and wild Pacific oysters descending from the farm (Reise 1998; Moehler et al. 2011; Reise et al. 2017a). Since this is the site of the first record and still the locality with the highest infestation and there is no other oyster farm in the entire region, we suspect that the establishment of $P$. websteri in the northern Wadden Sea may be related to the oyster imports conducted by that farm. Previous studies indicated that the oyster farm at Sylt served as origin for the co-introduction of other non-indigenous organisms that were formerly not recorded in the Wadden Sea before (Reise 1998; Wolff and Reise 2002). The distant occurrence of $P$. websteri near the island of Texel in the western Wadden Sea with no positive sites in between may have another origin (see below).

Blisters were also recorded at four other locations at the northern end of Sylt and at one location at the southern end. Apart from the site in the tidal basin south of Sylt, which is separated from the northern basin by a causeway connecting the island with the mainland, all locations at Sylt are in close distance to the oyster farm. Besides planktotrophic larvae, $P$. websteri is also capable of producing adelphophagic larvae (Simon 2015) that feed on unfertilised eggs and, therefore, have a short or no planktonic phase. Perhaps, a predominance of this mode of reproduction explains the rather limited dispersal found so far. In order to colonise the southern tidal basin of Sylt, larvae would have to travel southward along the exposed west coast of Sylt and then back into the Wadden Sea, resulting in a minimum distance of $50 \mathrm{~km}$. This would require dispersal by planktotrophic larvae. Alternatively, birds, mussel fishery, or leisure boats with fouling oysters might have served as vectors. Given the limited range extension at Sylt over the past 6 years, natural dispersal from Sylt to Texel, almost $500 \mathrm{~km}$ of coastline, seems rather unlikely and a different origin can be assumed. Hull fouling might have been the vector, as there are harbours (navy, ferry) with regular traffic in the Bay where P. websteri was observed at Texel.

At the location close to the oyster farm at Sylt, the studied oyster shells generally showed high prevalence of polydorins
Table 2 Overview of the number of blisters (sampled in March 2017) as well as the number of $P$. websteri per live oyster (intensity, sampled in August and October 2017) of individual $P$. websteri encountered in Pacific oysters at Blidselbucht and Mokbaai in 2017

\begin{tabular}{|c|c|c|c|c|c|}
\hline Location & Year & Month & Host length $(\mathrm{cm})$ & number of blisters & intensity of $P$. websteri \\
\hline Blidselbucht & 2017 & 3 & 5.5 & 1 & NA \\
\hline Blidselbucht & 2017 & 3 & 10 & 5 & NA \\
\hline Blidselbucht & 2017 & 3 & 10.5 & 3 & NA \\
\hline Blidselbucht & 2017 & 3 & 11 & 3 & NA \\
\hline Blidselbucht & 2017 & 3 & 12 & 2 & NA \\
\hline Blidselbucht & 2017 & 3 & 13 & 3 & NA \\
\hline Blidselbucht & 2017 & 3 & 14 & 8 & NA \\
\hline Blidselbucht & 2017 & 3 & 14.5 & 2 & NA \\
\hline Blidselbucht & 2017 & 3 & 15.5 & 12 & NA \\
\hline Blidselbucht & 2017 & 8 & 5 & NA & 2 \\
\hline Blidselbucht & 2017 & 8 & 6.7 & NA & 1 \\
\hline Blidselbucht & 2017 & 8 & 7.8 & NA & 11 \\
\hline Blidselbucht & 2017 & 8 & 7.9 & NA & 5 \\
\hline Blidselbucht & 2017 & 8 & 8.7 & NA & 1 \\
\hline Blidselbucht & 2017 & 8 & 9.7 & NA & 1 \\
\hline Blidselbucht & 2017 & 8 & 9.7 & NA & 8 \\
\hline Blidselbucht & 2017 & 8 & 10.3 & NA & 1 \\
\hline Mokbaai & 2017 & 10 & 14.5 & NA & 1 \\
\hline Mokbaai & 2017 & 10 & 15.4 & NA & 1 \\
\hline Mokbaai & 2017 & 10 & 15.4 & NA & 3 \\
\hline
\end{tabular}

NA indicates information that was not registered 
and of oysters showing blisters, ranging between 42 and $87 \%$. Similar values are reported from other locations where the polychaete has been introduced. For instance, in Washington State at the US Pacific coast, where $P$. websteri was recently confirmed to be present, $41 \%$ of Pacific oysters showed blisters and burrows that in many cases were linked to $P$. websteri (Martinelli et al. 2020). At locations where P. websteri is established for several decades, such as along the US Atlantic coast and Hawaii, the polychaete reaches prevalence up to 100\% (Rice et al. 2018). In respect to the infestation intensities, the observed numbers of $P$. websteri in oysters from the Wadden Sea seem comparably low. Up to 11 individuals of $P$. websteri and a maximum of 12 blisters were recorded within a single oyster, whereas previous studies report worm numbers exceeding 100 individuals per host in highly infected areas (Simon \& Sato-Okoshi 2015; Rice et al. 2018).

Despite a broad range of host species is known for P. websteri (Simon and Sato-Okoshi 2015) and other potential host species co-exist with oysters in the Wadden Sea, we only found the polychaete in Pacific oysters. Probably P. websteri prefers the relatively thick oyster shells over the much thinner shells of other species, like mussels Mytilus edulis. Such a preference for oyster shells has also been reported from the native shell-boring polychaete Polydora ciliata infecting mussels and oysters in the Wadden Sea (Goedknegt et al. 2019).

Although the infestation with $P$. websteri in farmed oysters was not explicitly quantified here, it seems that the species currently does not pose a threat to the oyster industry on Sylt (pers. comm. workers of the oyster farm). It is possible that the farmed oysters feature environmental conditions that are less favourable for $P$. websteri compared with the ones encountered at the surrounding wild oysters. For instance, the cultured oysters are kept on trestles about $0.35 \mathrm{~m}$ above the surface (Reise 1998), and it is known that tidal exposure reduces the infestation with P. websteri (Littlewood et al. 1992; Handley and Bergquist 1997). Furthermore, a lower siltation, which is probably caused by the regular manual turning of the oyster mesh bags to prevent oysters from cementing together, also reduces infestation success of the polychaetes (Clements et al. 2017). However, given that the polychaete is considered a serious pest in commercial marine aquaculture in other regions around the globe (Whitelegge 1890; Lunz 1941; Loosanoff and Engle 1943; Bailey-Brock and Ringwood 1982; Ogburn et al. 2007), further investigations on the spread and population development of $P$. websteri are warranted.

In conclusion, our study shows that the shell-boring polychaete Polydora websteri invaded the intertidal of the Wadden Sea. The most parsimonious explanation of its introduction is via imports of Pacific oysters, as individuals of $P$. websteri concentrate in oysters in the vicinity of the oyster culture. The dispersal of the species seems to be rather slow, and specimens are so far only found in wild oysters with relatively low intensities. With publishing the first record at the European Atlantic coast, we intend to alert other investigators and oyster farmers along the Atlantic coastline of Europe to the occurrence of $P$. websteri. Since we know of no direct transfers of Pacific oysters from overseas to the two localities where we encountered this polydorin, we suspect that there are more sites in Western Europe where P. websteri has established but remained unnoticed so far.

Acknowledgements We are indebted to Ondre Kapoun, who recognized a worm in an oyster he wanted to eat for lunch and thus bringing us on the track for the current study. We thank David Bello Jimenez, Mark Bouwmeester, Marvin Brandjes, Sarah Brandt, and Sascha Kuipers for helping in sampling and processing of the samples. Eike Petersen is thanked for performing the molecular lab work. Christian Buschbaum and Marieke Feis are thanked for providing live molluscs that were inspected for blisters. We further appreciate the valuable feedback on an earlier draft by two anonymous reviewers.

Funding Open Access funding provided by Projekt DEAL.

\section{Compliance with ethical standards}

Conflict of interest The authors declare that they have no conflict of interest.

Ethical approval All applicable international, national, and institutional guidelines for animal testing, animal care, and use of animals were followed by the authors.

Sampling and field studies All necessary permits for sampling and observational field studies have been obtained by the authors from the competent authorities. The study is compliant with CBD and Nagoya protocols.

Data availability All data generated or analysed during this study are included in this published article. The sequences of the two $P$. websteri specimens were deposited in GenBank under the accession numbers MT269755 and MT269756.

Authors' contribution All authors contributed to the study conception and design. DL carried out the initial survey in 2014. JK performed the systematic survey in 2017. KR helped with the initial survey and reported on $P$. websteri occurrence in subsequent years. KMW generated and analysed molecular data. AMW compiled the information and wrote the manuscript with significant contributions of all other authors. All authors read and approved the final manuscript.

Open Access This article is licensed under a Creative Commons Attribution 4.0 International License, which permits use, sharing, adaptation, distribution and reproduction in any medium or format, as long as you give appropriate credit to the original author(s) and the source, provide a link to the Creative Commons licence, and indicate if changes were made. The images or other third party material in this article are included in the article's Creative Commons licence, unless indicated otherwise in a credit line to the material. If material is not included in the article's 
Creative Commons licence and your intended use is not permitted by statutory regulation or exceeds the permitted use, you will need to obtain permission directly from the copyright holder. To view a copy of this licence, visit http://creativecommons.org/licenses/by/4.0/.

\section{References}

Ambariyanto, Seed R (1991) The infestation of Mytilus edulis Linnaeus by Polydora ciliata (Johnston) in the Conwy estuary, North Wales. J Molluscan Stud 57:413-424. https://doi.org/10.1093/mollus/57.4.413

Bailey-Brock JH, Ringwood A (1982) Methods for control of the mud blister worm, Polydora websteri, in Hawaiian oyster culture. Sea Grant Q 4:1-6

Barros TL, Simone C, Santos G et al (2017) Morphology and larval development of Polydora cf. websteri (Polychaeta : Spionidae) in a tropical region of North-Eastern Brazil. J Nat Hist 51:(1920)1169-1181. https://doi.org/10.1080/00222933.2017.1316426

Blake JA (1969) Systematics and ecology of Shell-boring polychaetes from New England. Am Zool 9:813-820. https://doi.org/10.1093/ $\mathrm{icb} / 9.3 .813$

Boonzaaier MK, Neethling S, Mouton A, Simon CA (2014) Polydorid polychaetes (Spionidae) on farmed and wild abalone (Haliotis midae) in South Africa: an epidemiological survey. African J Mar Sci 36:369-376. https://doi.org/10.2989/1814232X.2014.952249

Buschbaum C, Buschbaum G, Schrey I, Thieltges DW (2007) Shellboring polychaetes affect gastropod shell strength and crab predation. Mar Ecol Prog Ser 329:123-130. https://doi.org/10.3354/ meps329123

Clements JC, Bourque D, McLaughlin J et al (2017) Siltation increases the susceptibility of surface-cultured eastern oysters (Crassostrea virginica) to parasitism by the mudworm Polydora websteri. Aquac Res 48:4707-4717. https://doi.org/10.1111/are.13292

Edgar RC (2004) MUSCLE: multiple sequence alignment with high accuracy and high throughput. Nucleic Acids Res 32:1792-1797. https://doi.org/10.1093/nar/gkh340

Elton CS (1958) The ecology of invasions by animals and plants. Methuen, London, UK, Dordrecht

Feis ME, Goedknegt MA, Arzul I et al (2019) Global invasion genetics of two parasitic copepods infecting marine bivalves. Sci Rep 9:1-16. https://doi.org/10.1038/s41598-019-48928-1

Fourment M, Holmes EC (2016) Seqotron: a user-friendly sequence editor for mac OS X. BMC Res Notes 9:106. https://doi.org/10.1186/ s13104-016-1927-4

Goedknegt MA, Feis ME, Wegner KM et al (2016) Parasites and marine invasions: ecological and evolutionary perspectives. J Sea Res 113: 11-27. https://doi.org/10.1016/j.seares.2015.12.003

Goedknegt MA, Nauta R, Markovic M et al (2019) How invasive oysters can affect parasite infection patterns in native mussels on a large spatial scale. Oecologia 190:99-113. https://doi.org/10.1007/ s00442-019-04408-x

Handley SJ (1995) Spionid polychaetes in Pacific oysters, Crassostrea gigas (Thunberg) from Admiralty Bay, Marlborough sounds, New Zealand. New Zeal J Mar Freshw Res 29:305-309. https://doi.org/ 10.1080/00288330.1995.9516665

Handley SJ, Bergquist PR (1997) Spionid polychaete infestations of intertidal pacific oysters Crassostrea gigas (Thunberg), Mahurangi harbour, northern New Zealand. Aquaculture 153:191-205. https:// doi.org/10.1016/S0044-8486(97)00032-X
Herbert RJH, Humphreys J, Davies CJ et al (2016) Ecological impacts of non-native Pacific oysters (Crassostrea gigas) and management measures for protected areas in Europe. Biodivers Conserv 25: 2835-2865. https://doi.org/10.1007/s10531-016-1209-4

Katsanevakis S, Zenetos A, Belchior C, Cardoso AC (2013) Invading European seas: assessing pathways of introduction of marine aliens. Ocean Coast Manag 76:64-74. https://doi.org/10.1016/j. ocecoaman.2013.02.024

Kent RML (1979) The influence of heavy infestations of Polydora ciliata on the flesh content of Mytilus edulis. J Mar Biol Assoc United Kingdom 59:289-297. https://doi.org/10.1017/S0025315400042594

Littlewood DTJ, Wargo RN, Kraeuter JN, Watson RH (1992) The influence of intertidal height on growth, mortality and Haplosporidium nelsoni infection in MSX mortality resistant eastern oysters, Crassostrea virginica (Gmelin, 1791). J Shellfish Res 11:59-64

Lleonart M, Handlinger J, Powell M (2003) Spionid mudworm infestation of farmed abalone (Haliotis spp.). Aquaculture 221:85-96. https://doi.org/10.1016/S0044-8486(03)00116-9

Loosanoff VL, Engle JB (1943) Polydora in oysters suspended in the water. Biol Bull 85:69-78. https://doi.org/10.2307/1538270

Lucas JS (2019) Bivalve Molluscs. In: Lucas JS, Southgate PC, Tucker CS (eds) aquaculture: farming aquatic animals and plants: third edition. Pp 549-571

Lunz GR (1941) Polydora, a pest in South Carolina oysters. Jour Elisa Mitchell Sci Soc Chapel Hill 57:273-283

Mack RN, Simberloff D, Lonsdale WM et al (2000) Biotic invasions: causes, epidemiology, global consequences, and control. Ecol Appl 10:689-710

Martinelli JC, Lopes HM, Hauser L et al (2020) Confirmation of the shell-boring oyster parasite Polydora websteri (Polychaeta: Spionidae) in Washington state, USA. Sci Rep 10:3961. https:// doi.org/10.1038/s41598-020-60805-w

McKindsey CW, Landry T, O'Beirn FX, Davies IN (2007) Bivalve aquaculture and exotic species: a review of ecological considerations and management issues. J Shellfish Res 26:281-294. https://doi.org/10. 2983/0730-8000(2007)26[281:BAAESA]2.0.CO;2

Moehler J, Wegner KM, Reise K, Jacobsen S (2011) Invasion genetics of Pacific oyster Crassostrea gigas shaped by aquaculture stocking practices. J Sea Res 66:256-262. https://doi.org/10.1016/j.seares. 2011.08.004

Ogburn D, White I, Mcphee D (2007) The disappearance of oyster reefs from eastern Australian estuaries - impact of colonial settlement or mudworm invasion? Coast Manag 35:271-287. https://doi.org/10. 1080/08920750601169618

Radashevsky VI (1999) Description of the proposed lectotype for Polydora websteri Hartman in Loosanoff \& Engle, 1943 (Polychaeta: Spionidae). Ophelia 51:107-113. https://doi.org/10. 1080/00785326.1999.10409402

Radashevsky VI (2012) Spionidae (Annelida) from shallow waters around the British Islands: an identification guide for the NMBAQC scheme with an overview of spionid morphology and biology. Zootaxa 35:135. https://doi.org/10.11646/zootaxa.3152.1.1

Read GB (2010) Comparison and history of Polydora websteri and $P$. haswelli (Polychaeta: Spionidae) as mud-blister worms in New Zealand shellfish. New Zeal J Mar Freshw Res 44:83-100. https:// doi.org/10.1080/00288330.2010.482969

Reise K (1998) Pacific oysters invade mussel beds in the European Wadden Sea. Senckenberg Marit 28:167-175. https://doi.org/10. 1007/BF03043147

Reise K, Buschbaum C, Büttger H et al (2017a) Invasion trajectory of Pacific oysters in the northern Wadden Sea. Mar Biol 164:68. https://doi.org/10.1007/s00227-017-3104-2 
Reise K, Buschbaum C, Büttger H, Wegner MK (2017b) Invading oysters and native mussels: from hostile takeover to compatible bedfellows. Ecosphere 8:e01949. https://doi.org/10.1002/ecs2.1949

Rice LN, Lindsay S, Rawson P (2018) Genetic homogeneity among geographically distant populations of the blister worm Polydora websteri. Aquac Environ Interact 10:437-446. https://doi.org/10. 3354/AEI00281

Ruesink JL, Lenihan HS, Trimble AC et al (2005) Introduction of nonnative oysters: ecosystem effects and restoration implications. Annu Rev Ecol Evol Syst 36:643-689. https://doi.org/10.1146/annurev. ecolsys.36.102003.152638

Sato-Okoshi W (1999) Polydorid species (Polychaeta: Spionidae) in Japan, with descriptions of morphology, ecology and burrow structure. 1. Boring species. J Mar Biol Assoc United Kingdom 79:831848. https://doi.org/10.1017/S0025315498001003

Sato-Okoshi W, Abe H (2013) Morphology and molecular analysis of the $18 \mathrm{~S}$ rRNA gene of oyster shell borers, Polydora species (Polychaeta: Spionidae), from Japan and Australia. J Mar Biol Assoc United Kingdom 93:1279-1286. https://doi.org/10.1017/ S002531541200152X

Simon CA (2015) Observations on the composition and larval developmental modes of polydorid pests of farmed oysters (Crassostrea gigas) and abalone (Haliotis midae) in South Africa. Invertebr Reprod Dev 59:124-130. https://doi.org/10.1080/07924259.2015. 1044675

Simon CA, Sato-Okoshi W (2015) Polydorid polychaetes on farmed molluscs: distribution, spread and factors contributing to their success. Aquac Environ Interact 7:147-166. https://doi.org/10.3354/ aei00138

Surugiu V (2012) Systematics and ecology of species of the Polydoracomplex (Polychaeta: Spionidae) of the Black Sea. Zootaxa 65:4565. https://doi.org/10.11646/zootaxa.3518.1.3
Troost K (2010) Causes and effects of a highly successful marine invasion: case-study of the introduced Pacific oyster Crassostrea gigas in continental NW European estuaries. J Sea Res 64:145-165. https://doi.org/10.1016/j.seares.2010.02.004

van der Meer J, Dankers N, Ens BJ et al (2019) The birth, growth and death of intertidal soft-sediment bivalve beds: no need for largescale restoration programs in the Dutch Wadden Sea. Ecosystems 22:1024-1034. https://doi.org/10.1007/s10021-018-0320-7

Vitousek PM, D'Antonio CM, Loope LL, Westbrooks R (1996) Biological invasions as global environmental change. Am Sci 84: 468-478

Waser AM, Deuzeman S, Kangeri AKW et al (2016) Impact on bird fauna of a non-native oyster expanding into blue mussel beds in the Dutch Wadden Sea. Biol Conserv 202:39-49. https://doi.org/ 10.1016/j.biocon.2016.08.007

Whitelegge T (1890) Report on the worm disease affecting the oysters on the coast of New South Wales. Rec Aust Museum 1:41-54. https:// doi.org/10.3853/j.0067-1975.1.1890.1224

Wolff WJ, Reise K (2002) Oyster imports as a vector for the introduction of alien species into northern and Western European coastal waters. Invasive Aquat Species Eur Distrib Impacts Manag:193-205. https://doi.org/10.1007/978-94-015-9956-6_21

Ye L, Cao C, Tang B et al (2017) Morphological and molecular characterization of Polydora websteri (Annelida: Spionidae), and larvae using mitochondrial COI gene as a molecular marker. Pak J Zool 49: 699-710

Publisher's note Springer Nature remains neutral with regard to jurisdictional claims in published maps and institutional affiliations. 